\title{
Peculiarities of Protection of Rights and Interests of Heirs: Theoretical Aspects
}

\author{
Yuri O. Zaika ${ }^{1, *}$, Oleksandr Ye. Kukhariev², Volodymyr L. Skrypnyk ${ }^{3}$ and Aliesia A. Mytnyk ${ }^{3}$ \\ ${ }^{1}$ Department of Private Law Problems, Academician F.H. Burchak Scientific and Research Institute of Private \\ Law and Entrepreneurship of the National Academy of Legal Sciences of Ukraine, Kyiv, Ukraine \\ ${ }^{2}$ Department of Civil Law and Procedure, Kharkiv National University of Internal Affairs, Kharkiv, Ukraine \\ ${ }^{3}$ Department of Branch Legal Sciences, Kremenchuk Mykhailo Ostrohradskyi National University, \\ Kremenchuk, Ukraine
}

\begin{abstract}
The relevance of this study is due to the necessity to ensure the proper exercise of subjective civil rights in the field of inheritance law. Protection in inheritance is related to the general right to protection. Due to the peculiarities of inheritance law as a sub-branch of civil law, it has its own specifics, which is manifested primarily in the definition of special ways to protect violated unrecognized or challenged rights. In addition, the protection of the rights of heirs takes place only within the inheritance relationship, which is characterized by a long nature. The purpose of the article is to identify the features of protection of subjective civil rights of heirs in the field of inheritance. This necessitates the use of special methodological approaches that will identify the characteristics of protection of the rights of heirs, as well as research methods such as dogmatic, formal-logical, systematic, comparative law. The article analyses the recognition of the right of ownership of inherited property in court and proves that this exceptional method of protection is used if there are obstacles to the notarization of inheritance rights. The most typical and widespread special ways to protect the rights of heirs are considered: removal from the right to inherit, invalidation of the will, change of the order of obtaining the right to inherit, reduction of the size of the obligatory share in the inheritance. The outlined issues were not widely covered in the legal literature, as the attention of scholars was mainly in the perspective of clarifying the legal nature of protection and defence, the ratio of forms and methods of protection of subjective civil rights, analysis of general methods of protection of subjective civil rights. That is why this work is an important contribution to outlining the issue of inheritance law and attracting due attention of the scientific community.
\end{abstract}

Keywords: Inheritance, hereditary legal relations, Civil Code of Ukraine, method of protection, violation of rights.

\section{INTRODUCTION}

The protection of the rights of heirs takes place exclusively within the limits of the existence of inheritance legal relations that arise from the time of the opening of the inheritance and end with its registration. In order to apply a certain method of protection, an heir must accept the inheritance in the manner and for the period specified by civil law. Until then, the rights of an heir cannot be considered violated, unrecognized or challenged. Ways to protect the rights of heirs can be classified into two groups: general and special. The main means of protecting the rights of heirs is a hereditary claim. Special methods of protection of the rights of heirs, which can be applied only in the field of inheritance law, include: removal from the right to inherit; invalidation of the will; recognition of the right to a mandatory share in the inheritance; reduction of the size of the obligatory share in the inheritance; appointment of an executor of the will; removal of an executor of the will from the exercise of his powers; changing the order of obtaining the right

*Address correspondence to this author at the Academician F.H. Burchak Scientific and Research Institute of Private Law and Entrepreneurship of the National Academy of Legal Sciences of Ukraine, Kyiv, Ukraine; Tel: (044) 28670-98; E-mail: prof.zaika6442-1@uohk.com.cn to inherit; determination of an additional term for acceptance of inheritance; interpretation of the will; making changes to the inheritance certificate; invalidation of the inheritance right certificate.

Not all special ways to protect the rights of heirs are directly enshrined in the sixth book of the Civil Code of Ukraine, which significantly expands the legal freedom of heirs in terms of the application of one or another method (Civil Code of Ukraine 2003). The range of grounds for removal from the right to inherit, recognition of the will as invalid, as well as changes in the order of obtaining the right to inherit in court is defined by law exhaustively and imperatively. On the contrary, the legislator formulates an open (nonexhaustive) list of grounds for reducing the size of the obligatory share in the inheritance, which allows taking into account the peculiarities of relationships in a particular family and is fully consistent with the principle of freedom of will. Debt collection at the suit of the testator's creditor is not a way to protect the rights of the heirs, as it is aimed at restoring the property status of another subject of civil law - the testator's creditor. A wide range of rights of heirs (the right to accept the inheritance and to refuse to accept it, the possibility of concluding various agreements after the opening of the 
inheritance) requires giving them effective opportunities to protect such rights. That is why the protection of the rights of heirs is a guarantee of the exercise of the most subjective civil law, gives it real value and completeness.

Inheritance law is the most conservative branch of civil law, as it is based on national traditions, the special mentality of society, formed over the centuries, which necessitates the study of the history of individual institutions of inheritance law and the peculiarities of methodological approach and research methods. World experience shows the objective nature of the unity of the optimal balance of private and public interests, so in this perspective, the main institutions of inheritance law were considered. At the same time, the legal regulation of inheritance relations is carried out not only in terms of taking into account the interests of the subjects of these legal relations but also in terms of how these legal relations affect the interests of subjects of related legal relations (Zaika et al. 2020).

According to the traditional concept, the right to protection is an integral part of subjective law. The mechanism of protection of subjective civil rights is determined by the nature of civil legal relations. At the same time, the legislator, having defined specific ways to protect civil rights and interests, did not establish the definition of "method of protection". The method of protection of subjective civil law means the substantive and legal measures of a coercive nature, by means of which the restoration (recognition) of violated, disputed or unrecognized rights, restoration of property of the victim and influence on the violator are conducted (Kot, 2017). By their legal nature, the methods of protection have a substantive nature, because they are enshrined in substantive law and directly protect the rights and interests of the subjects of civil law.

The status of an heir can be acquired by a person directly, when a will in his favour, or directly belonging to the queue of heirs, which is called for an inheritance, or indirectly - if the inheritance is not accepted by direct heirs or their removal as unworthy or inheriting the right to compulsory share (Zaika, 2020).

Since the inheritance rights are protected primarily by the court, the problem of defining ways to protect civil rights and interests in the field of inheritance is extremely important for the actual implementation in public relations of Article 13 of the Convention for the Protection of Human Rights and Fundamental Freedoms of 1950, according to which everyone whose rights and freedoms recognized in this Convention has been violated, have the right to an effective remedy before a national authority, even if such violation has been committed by persons exercising their official powers.

\section{GENERAL PRINCIPLES OF PROTECTION OF THE RIGHTS OF HEIRS: A REVIEW}

For the domestic legal system, it is traditional to single out the so-called "general methods of protection", which are characterized by the universality of application. Such methods are structurally enshrined in Article 16 of the Civil Code of Ukraine and include: 1) recognition of the right; 2 ) recognition of the transaction as invalid; 3 ) termination of the action that violates the right; 4) restoration of the situation that existed before the violation; 5) compulsory performance of duty in kind; 6 ) change of legal relationship; 7) termination of the legal relationship; 8) compensation for damages and other methods of compensation for property damage; 9) compensation for moral (non-pecuniary) damage; 10) recognition of illegal decisions, actions or omissions of a body of state power, a body of power of the Autonomous Republic of Crimea or a body of local self-government, their officials (Civil Code of Ukraine 2003). The court may protect a civil right or interest in another way established by contract or law or by a court in cases specified by law. This testifies to an open (inexhaustible) list of ways of protection, which is one of the most important guarantees for the unimpeded exercise by subjects of their rights and interests. It is worth noting that "civil dispute resolution" and "civil dispute regulation" are not identical concepts, because "settle the dispute" is a component of the broader concept of "resolve the dispute" (Vasylyna, 2018).

The protection of the rights of heirs is associated with the peculiarities of inheritance, which have a pronounced specificity. These are primarily from the time of the discovery of the inheritance, which national law links to the death of a person or the declaration of his or her death. Until the opening of the inheritance, a person does not acquire the status of the heir. In order for an heir to acquire the right to protection, he must accept the inheritance in the manner and for the period specified by law. This is how a person's consent to become the universal successor of a testator is expressed. Until the inheritance is accepted, the rights of an heir may not be considered violated, unrecognized or challenged. A person who has the right to inherit, from the moment of opening the 
inheritance cannot be considered the subject of the relationship in which the testator was. It does not yet have the right of ownership, the right of claim, the right of mortgage and any other of those that belonged to the testator. In order to become a subject of rights and obligations, an heir must accept the inheritance (Shershenevych 2005).

Some scholars, depending on the dynamics of the inheritance relationship, identify the methods of protection used before the acceptance of the inheritance by heirs and after this fact. Thus, at the first stage, heirs have the right to apply such methods of protection, which are aimed at the protection of heritage, in particular, taking measures to protect the inherited property, its management. At the same stage, permissible methods of protection aimed at confirming (establishing) their status as heirs, carried out by recognizing the heirs, removing from the right to inherit other heirs, changing the order of obtaining the right to inherit, etc. (Spasibo-Fateyeva et al. 2014).

The vulnerability of this position is due to the fact that its supporters consider taking measures to protect inherited property and inheritance management as protection, but the rights of an heir at this stage of the inheritance are not violated or challenged, because an heir has not yet exercised his right to inherit and it does not belong to him. Similarly, only an heir who has accepted the inheritance in the manner and terms specified by civil law may raise the issue of removal from the right to inherit and change the order of obtaining the right to inherit by going to court.

The legal status of the heir is limited in time by the duration of the inheritance relationship, which arises from the time of the opening of the inheritance and is terminated by its registration by the heirs. After acquiring the right of ownership of the inherited property, the heir becomes the owner of such property, the relevant legal relationship is transformed into a property relationship. Therefore the heir acquires a different legal status of the owner. This circumstance significantly affects the protection of the violated, unrecognized or challenged right, which will be applied in legal relations of another kind. That is why the right to choose the method of protection belongs to an heir, taking into account the specifics of inheritance. Thus, in some cases, the method of protection is due to the type of inheritance. In particular, the will is interpreted by the court only within the relationship of inheritance by will.

On the contrary, it is possible to change the order of obtaining the right to inherit only by inheritance according to the law. The civil legislation of Ukraine imperatively outlines only two types of inheritance according to will and according to law. Although there is an additional type of inheritance in some foreign legal systems - a contract that combines the features of a civil contract and a will, i.e. has a dual legal nature (Germany, Czech Republic, Estonia).

It should be borne in mind that the method of protection of civil rights chosen by an heir must lead to the actual protection of the violated, unrecognized or challenged right or interest. Suppose such a right or interest is to be protected only in a certain way, and the one chosen by an heir can be used to protect other rights or interests than those for which an heir has applied to the court. In that case, the court finds the chosen method of protection improper and denies a claim. The main ways to protect the rights of heirs are lawsuits, with which he can go to court if he considers that there are obstacles to the exercise of inheritance rights granted to him by law.

\section{SPECIAL WAYS TO PROTECT THE RIGHTS OF HEIRS}

The choice of method of protection depends on two circumstances: the specifics of the law that needs protection and the nature of an offence. General remedies are universal in any area of private law. In turn, the special nature of methods of protection is due to the possibility of their application only within the hereditary legal relationship. This is fully consistent with their structural placement in the sixth book of the Civil Code of Ukraine "Inheritance Law" (Civil Code of Ukraine 2003). Of the greatest theoretical and practical interest are the special ways of protecting the rights of heirs, which include the following: removal from the right to inherit; invalidation of the will; recognition of the right to a mandatory share in the inheritance; reduction of the size of the obligatory share in the inheritance; appointment of the executor of the will; removal of the executor of the will from the exercise of his powers; changing the order of obtaining the right to inherit; determination of an additional term for acceptance of inheritance; interpretation of the will; amendments to the inheritance certificate; invalidation of the inheritance right certificate.

At the same time, not all special methods of protection of the rights of heirs are directly enshrined in the relevant part of the Civil Code of Ukraine, which significantly expands the legal freedom of heirs in terms of the application of a particular method of 
protection. For example, an heir who has accepted the inheritance, but is deprived of the opportunity to formalize their rights within the notarial proceedings, may apply to the court for recognition of property rights by inheritance. This protection method is common in court practice and is used due to the lack of registration of ownership of a real estate by the testator, the loss of an heir of title documents to such property (Kukhariev 2019). It is important to keep in mind that recognizing the right to inherit in court is an exceptional way to be used if there are obstacles to the notarization of inheritance rights. As a general rule, inheritance rights are registered by a notary, and therefore the recognition of the right to the heir in court in all cases without exception will mean the performance by the court of notarial functions, which is inadmissible.

In addition, it should be noted that the law obliges an heir to satisfy the creditor's claims in full, but within the value of the inherited property. The heirs are obliged to satisfy the creditor's claims by a one-time payment unless otherwise agreed between heirs and the creditor. In the case of refusal of a one-time payment, the court at the request of the creditor imposes a penalty on the property that was transferred to heirs in kind. However, in this case, debt collection cannot be considered a way to protect the rights of heirs, as it is aimed at restoring the property status of another subject of civil law - the creditor of the testator. This article analyzes the most common and important special ways to protect the rights of heirs.

\section{Analysis of the Most Common Special Types of Protection of Inheritance Law}

Disqualifying from the right to inherit is one of the most common special methods of protection of inheritance rights, known to both national and foreign law. Guided by the norms of universal morality, the legislator determines the circle of persons who are excluded from inheritance, regardless of their family ties with the deceased, and in some cases, despite the previously expressed will of the testator. As a result of their illegal conduct, persons who are deprived by law of the right to inherit after a particular testator in the theory of civil law are called "unworthy" heirs. Disqualifying from the right to inherit is the deprivation of an heir of the right to inherit after a particular testator on the grounds directly established by law. Modern inheritance law provides a general rule - a person is excluded from inheritance for actions in which the inheritance would be unfair. Exclusion from the right to inherit is traditionally defined in the legal literature as a type and form of civil liability (Bezklubyi et al. 2014), which has a strong educational character, as the relevant provision of the law aims to prevent misconduct and provides negative consequences for violators of not only legal but also other social, including moral, norms (Desmond 2018).

Article 1224 of the Civil Code of Ukraine (2003) includes the heirs who are disqualified from the right to inherit:

- persons who intentionally took the life of the testator or any of the possible heirs or attempted to take their lives;

- $\quad$ persons who intentionally prevented the testator from making a will, amending or revoking the will, thereby contributing to the emergence of the right to inherit from themselves or other persons or contributed to the increase of their share in the inheritance.

The following are not entitled to inherit by law:

parents after a child in respect of whom they have been deprived of parental rights and their rights have not been restored at the time of the opening of the inheritance;

parents (adoptive parents) and adult children (adopted children), as well as other persons who evaded the obligation to maintain the testator, if this circumstance is established by the court;

- $\quad$ persons whose marriage is invalid or recognized as such by a court decision.

Traditionally, the state should respect the life of the family and minimally interfere in its life (Desmond 2018). At the same time, according to a court decision, a person may be removed from the right to inherit by law if it is established that he evaded assistance to the testator, who was helpless due to old age, serious illness or disability.

It should be borne in mind that deprivation of a person's right to inherit is a measure that should be applied only as a last resort, taking into account, above all, the nature of an heir's behaviour. The law defines a closed (exhaustive) list of grounds for removing an heir from the right to inherit, which excludes the possibility of applying the relevant rule to cases not directly provided by it. For example, a person cannot be deprived of the right to inherit in case of unfriendly 
relations with the testator, lack of communication with the latter. It should be added that the rule on removal from the right to inherit applies only to heirs-individuals and does not apply to cases of making a will in favour of a legal entity.

The analysis of foreign legislation shows that the range of grounds for removing an heir from the right to inherit is much wider than in Ukrainian law. For example, under Art. 3 of the Law of Bulgaria "On Inheritance" anyone who unreasonably accused the testator of committing a crime punishable by imprisonment cannot inherit (Law of Bulgaria... 1949). According to Article 756 of the Spanish Civil Code, the right to inherit is deprived, in particular: parents who abandon their children, force them into prostitution or commit lewd acts against them; persons convicted of actions directed against the testator, his wife (husband), descendants or ancestors; persons who have unreasonably accused the testator of committing a crime for which the law provides imprisonment for a long term; an adult heir who, knowing of the forcible death of the testator, did not declare this to the investigating authorities within one month from the date of the testator's death (Spanish Civil Code 1889). It is also possible to distinguish the exclusion from the right to inherit of an heir, who by deception or illegal threat forced the testator to make or cancel the will (Bürgerliches Gesetzbuch 1896, Law of Succession Act... 2008).

Recognition of a will as invalid as a way to protect the rights of heirs is used in the case when a will violates the requirements, compliance with which is necessary for its validity. It should be borne in mind that the invalidation of a will as a special method of protection of hereditary is not identical to such a general method of protection of civil rights and interests by the court as the invalidation of the transaction. This conclusion follows primarily from the legal nature of a will as a unilateral transaction. In addition, not the party to the transaction which is the testator, but another person, the heir has the possibility of going to court with a claim to recognize a will invalid, who has a significant influence on the application of the appropriate method of protection. In this case, inheritance by will is much less than inheritance by law, because it is directly related to the need to make a will for life. As Kelly rightly points out, disposing of property in the event of death not only stimulates a person to work and invest, which contributes to the accumulation of capital, but also is socially significant, strengthens family relationships and encourages children to care for their parents (Kelly 2013). However, most people are in no hurry to make wills. Thus, even in Great Britain, (including England and Wales), despite the "ageing" of the population, the desire to express their last will by making a testament does not increase (Sloan 2017).

According to Article 1257 of the Civil Code of Ukraine, a testament made by a person who did not have the right to do so, as well as a testament made in violation of the requirements for its form and certificate, is void (Civil Code of Ukraine 2003). Upon the claim of a person concerned, the court shall declare a testament invalid if it is established that the testator's will expression was not free and did not correspond to his intention. A testament can be declared invalid only if there are grounds specified in the law. It is important to note that the law does not provide for the possibility of making changes to the content of a testament after the opening of the inheritance, as this changes the will of a testator, which is unacceptable. The right to make changes to a testament, its cancellation belongs exclusively to a testator. Moreover, the invalidity of a separate order contained in the will does not result in the invalidity of the other part. For example, deprivation of the right to inherit a person who is entitled to a mandatory share in the inheritance, although invalid, does not automatically entail the invalidity of all other provisions that constitute the content of the will as a unilateral transaction. In essence, the invalidity of a testament is equal in legal consequences to the absence of a testament. An invalid testament does not give rise to the legal consequences to which it was directed (Spasibo-Fateyeva et al. 2016).

According to the legislation of Ukraine, the general limitation period of three years applies to claims for invalidity of a testament. The beginning of the statute of limitations on claims for invalidation of a testament begins from the day when a person learned or could learn about the violation of rights and the grounds for invalidation of a testament, but not before the opening of the inheritance. At the same time, in foreign legal systems, the statute of limitations on claims for invalidation of a will is determined differently. $§ 2082$ of the German Civil Code sets a time limit of one year for challenging a testament, which is calculated from the moment when a person entitled to challenge a testament knows of the existence of appropriate grounds. Moreover, contesting a testament is excluded if 30 years have passed since the opening of the inheritance (Bürgerliches Gesetzbuch 1896). Hungarian law sets a time limit for appealing a will of 5 years from the time of the opening of the inheritance. It 
is noteworthy that a person may waive his right to appeal a testament after the death of the testator (Civil Code of Hungary 2013). Pursuant to Article 44 of the Bulgarian Law "On Inheritance", a claim for invalidation of a testament may be filed within 3 years from the moment when a person learned about the reasons for the invalidity of a testament. However, in any case, this period may not exceed 10 years from the discovery of the inheritance (Law of Bulgaria.... 1949).

Judicial practice regarding the invalidation of a will or the invalidation of agreements concluded by a testator is diverse. However, the principle of res judicata does not in itself require national courts to adhere to precedents in similar cases; achieving consistency of legislation may take some time, and therefore the existence of periods of conflicting case law is allowed if such case law does not undermine legal certainty. This means that two courts, each in its own jurisdiction, are able to decide on similar (in fact and by law) cases, reaching heterogeneous, but still rational and reasoned conclusions (Vitkauskas and Dykov 2018).

\section{Analysis of Additional Special Types of Protection of Inheritance Rights}

Expansion of dispositive principles of regulation of inheritance law, taking into account the actual or admissible will of the testator led to the enshrinement in Ukrainian legislation of new ways to protect inheritance rights, which include, in particular, changing the order of inheritance. In essence, the mechanism of changing the order of receipt of the right to inherit is aimed at overcoming the mandatory rule, according to which heirs by law receive the right to inherit in line. Each subsequent line of heirs by law receives the right to inherit in the absence of the heirs of the previous line, removing them from the right to inherit, their nonacceptance of the inheritance or refusal to accept it. When establishing heirs, the law is based on the assumption of the most probable range of persons whom a testator would like to call for inheritance.

According to the civil legislation of Ukraine, a natural person who is an heir under the law of the following stages may, by the court decision, receive the right to inherit together with heirs of the order entitled to inherit, provided that he has long cared for, materially supported, assisted to the testator who was helpless due to old age, serious illness or disability. In the legal literature, it is rightly noted that civil liability in inheritance law can take the form of reducing the size of the heir's share when the order of inheritance by law changes by a court decision based on the principles of justice. Such a court decision causes negative consequences for an heir due to the reduction of his share in the inheritance (Zaika and Loviak 2014). The legal nature of the change of priority to inherit is defined in the Ukrainian legal doctrine ambiguously: as a type of incentive, as an actual gift (Romovska 2009, Fursa et al. 2007).

This method of protection can be applied, in particular, if the next of kin evaded the duty to care for the testator, who needed help due to old age, serious illness or injury, and such care was provided for a long time by other persons who, although and are included in the circle of heirs at law but are not close relatives of the testator. At the same time, the heirs of the previous line object to the change of the order of the right to inherit by concluding a relevant agreement.

1) Judicial practice shows that the grounds for the satisfaction of a claim to change the order of receipt of the right to inherit is a set of legal facts: custody of the testator, i.e. the provision of intangible services (communication, advice and consultations, congratulations on holidays);

2) material support of a testator;

3) providing any other material assistance to a testator - cleaning, cooking, apartment renovation;

4) committing such actions for a long time;

5) helpless condition of the testator, i.e. a condition in which a person is unable to provide for their own needs, caused by old age, serious illness or injury.

Moreover, the mere fact of providing financial assistance to a person, living with a testator for a long time without marriage registration does not indicate the existence of grounds for changing the order of obtaining the right to inherit (Kukhariev 2020).

In addition, heirs may use a special method of protection of their rights, such as reducing the size of the mandatory share in the inheritance. As a general rule, the provision on the size of the obligatory share in the inheritance is mandatory and is directly enshrined in law. In particular, according to Ukrainian law, minors, adult incapacitated children of the testator, incapacitated widow (widower) and incapacitated 
parents inherit, regardless of the content of the will, half of the share that would belong to each of them in case of inheritance by law (mandatory share). The obligatory share in the inheritance includes the value of things of ordinary home furnishings and use, the value of the testamentary disclaimer established in favour of a person entitled to the obligatory share, as well as the value of other things and property rights passed to him as heir. At the same time, the amount of the obligatory share in the inheritance may be reduced by the court, taking into account the relationship between the heirs who are entitled to the obligatory share in the inheritance and the testator, as well as other significant circumstances.

Attention should be paid to an open (nonexhaustive) list of grounds for reducing the size of the mandatory share in the inheritance, which significantly expands the legal freedom of the participants in inheritance and allows them to take into account the various life situations in a particular family. In the legal literature, such grounds include: the peculiarity of family relations, the performance of family and parental responsibilities to those who are entitled to a mandatory share in the inheritance; immoral behaviour of the obligatory heir in relation to a testator and other heirs; allocation to an heir of a certain share of property during the life of a testator; false court testimony against a testator in advance, accusing him of committing a crime; failure to notify that an attempt on the life of a testator is being prepared; threat to commit a crime against a testator or deprivation of services, which were previously provided to him (Romovska 2009, Zaika 2007).

In addition, the law does not specify the limits to which the court may reduce the size of the mandatory share in the inheritance, which allows protecting the rights and protected interests of heirs more effectively and is an element of legal freedom in the mandatory institution of mandatory share in the inheritance (Kukhariev 2020). It should be borne in mind that the application of this special method of protection of the rights of heirs is fully consistent with the last will of a testator, which aims to completely deprive a person of the right to a mandatory share in the inheritance.

\section{CONCLUSIONS}

The legal possibility of protecting the rights of heirs arises from the time of opening the inheritance and acceptance of the inheritance by heirs within the time and manner prescribed by law. Until these two legal facts occur, the rights of heirs cannot be considered violated, unrecognized or challenged. The main means of protecting the rights of heirs is a hereditary claim.

The civil legislation of Ukraine enshrines an inexhaustible list of ways to protect the rights of heirs. In particular, an heir may apply such a method of protection as the recognition of the right of ownership of the inherited property in court in the presence of obstacles in the notarization of inheritance rights.

Recovery of debt on the claim of a creditor is not a way to protect the rights of heirs, as it is aimed at restoring the property status of another subject of civil law - a creditor of a testator.

The range of grounds for removal from the right to inherit, recognition of a testament as invalid, as well as changes in the order of obtaining the right to inherit in court is defined by law exhaustively and imperatively. On the contrary, the legislator formulates an open (nonexhaustive) list of grounds for reducing the size of the mandatory share in the inheritance, which allows taking into account the peculiarities of the relationship in a particular family and is fully consistent with the principle of freedom of testament.

\section{REFERENCES}

Bezklubyi, Ihor, Nataliia Kuznietsova and Roman Maidanyk, R. 2014 Liability in Private Law. Kyiv: Gramota.

Bürgerliches Gesetzbuch. 1896. (https://www.gesetze-im-internet.de/ englisch_bgb/).

Civil Code of Hungary. 2013. (http://tdziegler.files.wordpress.com/ 2014/06/civil_code.pdf)

Civil Code of Ukraine. 2003. (https://zakon.rada.gov.ua/laws/show/ 435-15\#Text)

Desmond, Alan. 2018. "The Private Life of Family Matters: Curtailing Human Rights Protection for Migrants under Article 8 of the ECHR?". The European Journal of International Law 29(1): 261-279. https://doi.org/10.1093/ejil/chy008

Fursa, Svitlana, Yevhen Fursa and Oksana Klymenko. 2007. Inheritance Law: Notary. Advocacy. Court. Kyiv: Fursa.

Kelly, Daniel. 2013. "Restricting Testamentary Freedom: Ex Ante Versus Ex Post Justifications". Fordham Law Review 82(3): 1125-1185 https://doi.org/10.2139/ssrn.1990802

Kot, O.O. 2017. Exercise and Protection of Subjective Civil Rights: Problems of Theory and Judicial Practice. Kyiv: Alerta.

Kukhariev, Oleksandr. 2019. Analysis of The Ship's Practice of Referring to Civil Certificates of Decline. Kyiv: Alerta.

Kukhariev, Oleksandr. 2020. Inheritance Law of Ukraine. Kyiv: Alerta.

Law of Bulgaria for inheritance. 1949. (http://www.lex.bg/bg/laws/ Idoc/2121542657).

Law of Succession Act of Estonia. 2008. (https://www.riigiteataja.ee/ en/eli/506112013007/consolide)

Romovska, Zoryslava. 2009. Ukrainian Civil Law. Inheritance Right. Kyiv: Alerta. 
Shershenevych, Gabriel. 2005. Russian Civil Law Textbook. Volume 2. Moscow: Statut.

Sloan, Brian. 2017. Borkowski's Law of Succession (Third Edition). Oxford: Oxford University Press.

Spanish Civil Code. 1889. (http://derechocivil-ugr.es/attachments/ article/ 45/spanish-civil-code.pdf).

Spasibo-Fateyeva, Inna, Mykhailo Sibilev, Vitaliy Yarotskiy, and Valentyna Harkovskaya. 2014. The Kharkiv Civilistic School: Protection of Subjective Civil Rights and Interests. Kharkiv: Pravo.

Spasibo-Fateyeva, Inna, Oleh Pechenyi and Vasyl Krat. 2016. Kharkiv Civilist School: Facets of Inheritance Law. Kharkiv: Pravo.

Vasylyna, Natalia. 2018. "Resolution and Settlement of Civil Disputes". European Journal of Law and Political Sciences 1: 3-5.
Vitkauskas, Dovydas and Grigoriy Dykov. 2018. Protection of the Right to a Fair Trial in Accordance with the European Convention on Human Rights. Strasbourg: Council of Europe.

Zaika, Yuri and Oleh Loviak. 2014. Actual Problems of Inheritance Law. Kyiv: KNT; TsUL.

Zaika, Yuri, Vladimir Skrypnyk and Taras Sofiiuk. 2020. "Permanent Inheritance as an Object of Civil Rights: Theoretical Aspects". Asia Life Sciences 1: 153-170.

Zaika, Yuri. 2007. Inheritance Law in Ukraine: Formation and Development. Kyiv: KNT.

Zaika, Yuri. 2020. "Directions of Updating the Inheritance Legislation of Ukraine". Journal of the National Academy of Legal Sciences of Ukraine 1: 84-99. https://doi.org/10.37635/inalsu.27(1).2020.84-99

Received on 01-01-2021

DOI: https://doi.org/10.6000/1929-4409.2021.10.43

(C) 2021 Zaika et al.; Licensee Lifescience Global.

This is an open access article licensed under the terms of the Creative Commons Attribution Non-Commercial License (http://creativecommons.org/licenses/by-nc/3.0/) which permits unrestricted, non-commercial use, distribution and reproduction in any medium, provided the work is properly cited. 